\title{
Evaluation of the cholinomimetic actions of trimethylsulfonium, a compound present in the midgut gland of the sea hare Aplysia brasiliana (Gastropoda, 0 pisthobranchia)
}

\section{C.M. Kerchove ${ }^{1,2}$, R.P. M arkus ${ }^{1}$, J.C. Freitas ${ }^{1,2}$ and L.V. Costa-Lotufo ${ }^{3}$}

\author{
'Departamento de Fisiologia, Instituto de Biociências, U niversidade de São Paulo, \\ São Paulo, SP, Brasil \\ ${ }^{2}$ Centro de Biologia Marinha, U niversidade de São Paulo, São Sebastião, SP, Brasil \\ ${ }^{3}$ Departamento de Fisiologia e Farmacologia, Faculdade de Medicina, \\ Universidade Federal do Ceará, Fortaleza, CE, Brasil
}

\section{Correspondence \\ L.V. Costa-Lotufo \\ Departamento de Fisiologia e \\ Farmacologia, \\ Faculdade de Medicina \\ Universidade Federal do Ceará \\ Rua Coronel Nunes de Melo, 1127 \\ 60430-270 Fortaleza, CE \\ Brasil \\ Fax: + 55-85-288-8333 \\ E-mail: Ivcosta@ secrel.com.br \\ C.M. Kerchove is an undergraduate fellow of FAPESP. R.P. M arkus and L.V. Costa-Lotufo are research fellows of CNPq.}

Received July 5, 2001 Accepted February 20, 2002

\section{Abstract}

Trimethylsulfonium, a compound present in the midgut gland of the sea hare Aplysia brasiliana, negatively modulates vagal response, indicating a probable ability to inhibit cholinergic responses. In the present study, the pharmacological profile of trimethylsulfonium was characterized on muscarinic and nicotinic acetylcholine receptors. In rat jejunum the contractile response induced by trimethylsulfonium $\left(\mathrm{pD}_{2}=2.46 \pm 0.12\right.$ and maximal response $\left.=2.14 \pm 0.32 \mathrm{~g}\right)$ was not antagonized competitively by atropine. The maximal response $\left(\mathrm{E}_{\max }\right)$ to trimethylsulfonium was diminished in the presence of increasing doses of atropine $(\mathrm{P}<0.05)$, suggesting that trimethylsulfoniuminduced contraction was not related to muscarinic stimulation, but might be caused by acetylcholine release due to presynaptic stimulation. Trimethylsulfonium displaced $\left[{ }^{3} \mathrm{H}\right]$-quinuclidinyl benzilate from rat cortex membranes with a low affinity $\left(K_{\mathrm{i}}=0.5 \mathrm{mM}\right)$. Furthermore, it caused contraction of frog rectus abdominis muscles $\left(\mathrm{pD}_{2}=2.70 \pm\right.$ 0.06 and $\mathrm{E}_{\max }=4.16 \pm 0.9 \mathrm{~g}$ ), which was competitively antagonized by d-tubocurarine $(1,3$ or $10 \mu \mathrm{M})$ with a $\mathrm{pA}_{2}$ of 5.79 , suggesting a positive interaction with nicotinic receptors. In fact, trimethylsulfonium displaced $\left[{ }^{3} \mathrm{H}\right]$-nicotine from rat diaphragm muscle membranes with a $K_{\mathrm{i}}$ of $27.1 \mu \mathrm{M}$. These results suggest that trimethylsulfonium acts as an agonist on nicotinic receptors, and thus contracts frog skeletal rectus abdominis muscle and rat jejunum smooth muscle via stimulation of postjunctional and neuronal prejunctional nicotinic cholinoreceptors, respectively.
Key words

- Aplysia brasiliana

- Trimethylsulfonium

- Cholinergic systems

- Muscarinic acetylcholine receptors

- Nicotinic acetylcholine receptors 


\section{Introduction}

The opisthobranch gastropod molluscs, belonging to the family Aplysiidae, commonly called sea hares, are known to possess cholinomimetic principles in the midgut gland $(1,2)$. Many of these compounds, like murexine (3), dihydromurexine, senecioylcholine and tigloylcholine (4), act as agonists or antagonists on nicotinic acetylcholine receptors. Extracts from the midgut gland of the sea hare Aplysia brasiliana, which contain tetramethylammonium and trimethylsulfonium chloride (5), contract invertebrate muscles and prevent vagus-induced toad heart arrest (6). Preliminary studies suggest that trimethylsulfonium is the active principle of the extract (7).

The aim of the present study was to extend the studies with trimethylsulfonium looking for its cholinergic properties. Thus, we studied its effect on the binding to muscarinic and nicotinic receptors, as well as on classical cholinergic bioassay models. Binding studies were performed on rat cerebral cortex and diaphragm muscle membranes, while bioassays were done on rat jejunum and frog rectus abdominis muscle.

\section{Material and Methods}

\section{Drugs and chemicals}

Trimethylsulfonium $\left(\mathrm{C}_{3} \mathrm{H}_{9} \mathrm{SCl}, 112.4 \mathrm{~g}\right)$ has been isolated from the midgut gland of A. brasiliana in its chloride form; however, it has also been synthesized in the iodide form $\left(\mathrm{C}_{3} \mathrm{H}_{9} \mathrm{SI}, 203.9 \mathrm{~g}\right.$; Aldrich Chemical Company, Inc., Milwaukee, WI, USA), which was used in the present study. The following drugs were also used: carbachol, d-tubocurarine, acetyl-ß-methylcholine (methacholine), (-)-nicotine, atropine, phenylmethylsulfonylfluoride (PMSF), EDTA and Trizma Base (Sigma, St. Louis, MO, USA), (-)-Nmethyl- $\left[{ }^{3} \mathrm{H}\right]$-nicotine $\left(81.5 \mathrm{Ci} / \mathrm{mmol}\right.$; $\mathrm{NEN}^{\circledR}$ Sciences Products, Inc., Boston, MA, USA), $\left[{ }^{3} \mathrm{H}\right]$-quinuclidinyl benzilate ([$\left.{ }^{3} \mathrm{H}\right]-\mathrm{QNB}, 42$ $\mathrm{Ci} / \mathrm{mmol}$; ICN Biomedicals, Inc., Costa Mesa, CA, USA), and the salts (Quimitra S/A, Rio de Janeiro, RJ, Brazil).

\section{Functional studies}

Effect on muscarinic acetylcholine receptors. Male Wistar rats (Rattus norvegicus, 4-5 months old) were killed by decapitation. Tissues were prepared as described by Kobashi et al. (8). A segment of approximately $5 \mathrm{~cm}$ of the jejunum was isolated and washed to remove its contents with Tyrode solution $(137 \mathrm{mM} \mathrm{NaCl}, 2.7 \mathrm{mM} \mathrm{KCl}, 0.5$ $\mathrm{mM} \mathrm{NaH} \mathrm{PO}_{4}, 2.2 \mathrm{mM} \mathrm{MgCl} 2,3.6 \mathrm{mM}$ $\mathrm{CaCl}_{2}, 11.9 \mathrm{mM} \mathrm{NaHCO}_{3}$ and $5.5 \mathrm{mM}$ glucose). Jejunum segments (2 $\mathrm{cm}$ in length), resuspended in Tyrode solution $\left(35^{\circ} \mathrm{C}\right)$, were equilibrated for $30 \mathrm{~min}$ prior to the beginning of the experimental protocol. Isometric muscular contractions were recorded on a Narco polygraph (Narco BioSystems, Houston, TX, USA) through a Narco force transducer (model F-60) under an initial tension of $1 \mathrm{~g}$.

The antagonistic effect of trimethylsulfonium $(1,3$ and $10 \mathrm{mM})$ on muscarinic receptors was evaluated against concentrationresponse curves to acetyl- $\beta$-methylcholine (methacholine, $0.1 \mu \mathrm{M}$ to $0.3 \mathrm{mM}$ ), and compared to atropine $(0.1,1$ and $10 \mathrm{nM})$. The agonistic effect of trimethylsulfonium on muscarinic receptors was tested through cumulative concentration-response curves $(0.05$ to $12.8 \mathrm{mM})$ in the absence or in the presence of atropine (1, 10 or $100 \mathrm{nM})$. In these experiments, we obtained three consecutive and cumulative curves in response to the agonists at 1-h intervals. The last curve was obtained in the presence of a single concentration of the antagonist added to the bath immediately after completing the second curve, i.e., antagonists were incubated for $1 \mathrm{~h}$ before agonist testing. After each curve, the tissues were washed with Tyrode solution. 
Effect on nicotinic acetylcholine receptors. Frogs (Rana catesbeiana) were killed by decerebration. Each rectus abdominis muscle was removed, cut longitudinally into four strips, and transferred to a 7-ml organ bath containing Ringer solution $(109.1 \mathrm{mM}$

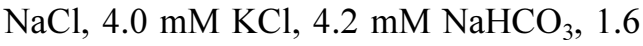
$\mathrm{mM} \mathrm{CaCl} 2$ and $3.9 \mathrm{mM}$ glucose) at room temperature $\left(25^{\circ} \mathrm{C}\right)$, under a tension of $1.5 \mathrm{~g}$. The isometric muscular responses were recorded on a Narco polygraph through a Narco force transducer (model F-60).

The agonistic effect of trimethylsulfonium ( 0.3 to $76.8 \mathrm{mM}$ ) on nicotinic receptors was evaluated through concentration-response curves, comparing its efficacy to the full-agonist carbachol $(8$ to $512 \mu \mathrm{M})$. In these experiments we obtained three consecutive and cumulative curves for the agonists at $1-\mathrm{h}$ intervals. The last curve was obtained in the presence of a single concentration of the antagonist d-tubocurarine $(1,3$ and $10 \mu \mathrm{M})$, added to the bath immediately after completing the second curve. After each curve, the tissues were washed with Tyrode solution.

Acetylcholine receptor binding assays. Male Wistar rats (4-5 months old) were killed by decapitation. Membranes rich in muscarinic receptors were obtained from rat brain cortex. The cortex was homogenized (Polytron Brinkmann homogenizer) in $20 \mathrm{ml}$ of ice-cold sucrose solution $(0.32 \mathrm{M})$, centrifuged $\left(500 \mathrm{~g}, 10 \mathrm{~min}, 4^{\circ} \mathrm{C}\right)$ and the pellet was discarded. The supernatant was further centrifuged $\left(40,000 \mathrm{~g}, 10 \mathrm{~min}, 4^{\circ} \mathrm{C}\right)$, and the resulting pellet was resuspended in 5 volumes of the assay buffer $\left(50 \mathrm{mM} \mathrm{Na} / \mathrm{K}^{+}\right.$ phosphate, $\mathrm{pH}$ 7.4). Aliquots of the crude membrane preparation were stored at $-70^{\circ} \mathrm{C}$ for up to one week.

Membranes rich in nicotinic receptors were obtained from rat diaphragm muscle. The muscle was isolated and homogenized in ice-cold 0.4 M Tris- $\mathrm{HCl}$ buffer, $\mathrm{pH} 7.5$, containing $10 \mathrm{mMEDTA}$ and $0.1 \mathrm{mM}$ PMSF and centrifuged $\left(5,000 \mathrm{~g}, 10 \mathrm{~min}, 4^{\circ} \mathrm{C}\right)$, and the pellet was discarded. The supernatant was further centrifuged $(40,000 \mathrm{~g}, 10 \mathrm{~min}$, $4^{\circ} \mathrm{C}$ ) and the resulting pellet was resuspended in 10 volumes of assay buffer $(20 \mathrm{mM}$ Tris$\mathrm{HCl}, \mathrm{pH} 7.5$, containing $0.1 \mathrm{mM}$ EDTA). Aliquots of the crude membrane preparation were stored at $-70^{\circ} \mathrm{C}$ for up to $24 \mathrm{~h}$.

Protein concentration was estimated by the method of Bradford (9) using bovine serum albumin as standard.

Competition binding assays were performed with a radioligand $\left(1 \mathrm{nM}\left[{ }^{3} \mathrm{H}\right]-\mathrm{QNB}\right.$, and $8 \mathrm{nM}\left[{ }^{3} \mathrm{H}\right]$-nicotine) for muscarinic and nicotinic receptors, respectively. For nicotinic binding assays, bovine serum albumin $(0.1 \mathrm{mg} / \mathrm{ml})$ was added to the Tris- $\mathrm{HCl}$ assay buffer. Nonspecific binding was defined as that occurring in the presence of atropine (2 $\mathrm{mM})$ or nicotine $(10 \mathrm{mM})$ for muscarinic and nicotinic receptors, respectively.

After 1-h incubation at room temperature, the samples were immediately filtered through Whatmann GF/B glass-fiber filters. The filters were washed three times with 4 $\mathrm{ml}$ of ice-cold buffer and placed in vials containing $5 \mathrm{ml}$ of scintillation cocktail (Ecolume, ICN Biomedicals, Inc.) and radioactivity was measured with a scintillation counter (Tri-Carb 2100TR, Packard, Camberra Co., Meriden, CT, USA).

\section{Statistical analysis}

The results are reported as means \pm SEM for both the competition and the concentration-response curves.

The $\mathrm{IC}_{50}$ was obtained by nonlinear regression with a $95 \%$ confidence interval $(95 \%$ $\mathrm{CI}$ ). For the binding assays, the $\mathrm{IC}_{50}$ of trimethylsulfonium and atropine were compared by the Student $t$-test $(\mathrm{P}<0.05)$. The dissociation constant $\left(K_{\mathrm{i}}\right)$ was obtained by the following formula:

$$
K_{\mathrm{i}}=\frac{\mathrm{IC}_{50}}{1+[\mathrm{L}] K_{\mathrm{D}}^{-1}}
$$

where [L] is the concentration of the radio- 
Figure 1. Inhibition of specific $\left[{ }^{3} \mathrm{H}\right.$-quinuclidinyl benzilate (QNB) binding to membranes isolated from rat cortex by atropine (filled squares, $\mathrm{N}=8$ ) or trimethylsulfonium (open squares, $\mathrm{N}=8$ ). Membranes were incubated with $\left[{ }^{3} \mathrm{H}\right]-\mathrm{QNB}$ and unlabeled compounds for $1 \mathrm{~h}$ at room temperature in $\mathrm{Na}^{+} / \mathrm{K}^{+}$phosphate buffer. Specific binding was calculated by subtracting the nonspecific binding measured in the presence of $2 \mathrm{mM}$ atropine from total binding $(\mathrm{T})$. Data are reported as means \pm SEM.

Figure 2. Cumulative concentration-response curves (1-h interval) for trimethylsulfonium in rat jejunum, in the absence (filled squares, $\mathrm{N}=9$ ) and in the presence of $1 \mathrm{nM}$ atropine (circles, $\mathrm{N}=7$ ), $10 \mathrm{nM}$ atropine (open squares, $\mathrm{N}=8$ ) and $100 \mathrm{nM}$ atropine (inverted triangles, $\mathrm{N}=5$ ). The antagonist was applied $1 \mathrm{~h}$ before the agonist. Data are reported as means \pm SEM. ligand used and $K_{\mathrm{D}}$ its dissociation constant. The $K_{\mathrm{D}}$ used for $\left[{ }^{3} \mathrm{H}\right]-\mathrm{QNB}$ was $0.06 \mathrm{nM}$, according to Yamamura and Snyder (10), and the $K_{\mathrm{D}}$ used for $\left[{ }^{3} \mathrm{H}\right]$-nicotine was $1 \mu \mathrm{M}$, according to Brioni et al. (11). The selectivity of trimethylsulfonium was calculated by the ratio of the inhibition constants for muscarinic and nicotinic receptors.

For the functional studies, $\mathrm{E}_{\max }$ and $\mathrm{pD}_{2}$ values are expressed as means \pm SEM calculated from individual experiments. The $\mathrm{E}_{\max }$ obtained for methacholine, carbachol and trimethylsulfonium in rat jejunum or frog rectus abdominis were compared by the Student $t$-test $(\mathrm{P}<0.05)$. The $\mathrm{E}_{\max }$ obtained for control and treated preparations were compared by one-way analysis of variance followed by the Newman-Keuls test.

The antagonist affinities (atropine and dtubocurarine) were determined by Equation I proposed by Arunlakshana and Schild (12). According to these investigators, if the blockade is competitive, a plot of the logarithm of
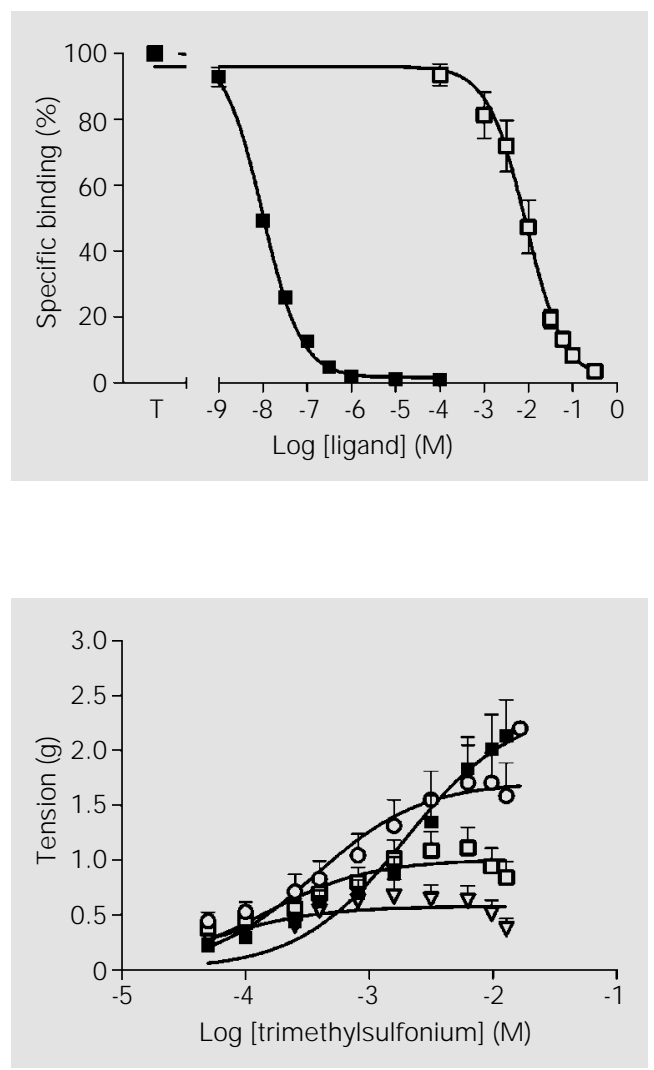

(dose ratio-1) against the negative logarithm of the molar concentration of the blocker (B) will yield a straight line with a slope of one and intercept along the abscissa at $\mathrm{pA}_{2}$, which under equilibrium conditions is equal to the negative logarithm of the dissociation constant of the antagonist (Equation II).

$$
\begin{gathered}
\log (\mathrm{DR}-1)=\eta \log [\mathrm{B}]+\log K_{\mathrm{B}} \\
\mathrm{pA}_{2}=-\log K_{\mathrm{B}}
\end{gathered}
$$

Schild analysis was performed by linear regression, and the slope of the straight line was obtained with SEM. The Graphpad Prism program was used for curve construction and statistical analysis (Intuitive Software for Science, San Diego, CA, USA).

\section{Results}

\section{Effect of trimethylsulfonium on muscarinic receptors}

In order to determine if trimethylsulfonium acts on muscarinic receptors, as suggested by the inhibition of vagus-induced toad heart arrest (6), its ability to displace $\left[{ }^{3} \mathrm{H}\right]-\mathrm{QNB}$ was tested (Figure 1). Trimethylsulfonium $\left(K_{\mathrm{i}}=0.5 \mathrm{mM}\right)$ displaced $\left[{ }^{3} \mathrm{H}\right]$ QNB with a very low affinity compared to atropine (0.6 nM).

The functional agonistic and antagonistic properties of trimethylsulfonium on muscarinic receptors were assessed in the rat isolated jejunum. Cumulative additions of the compound caused concentration-dependent contractions, with a $\mathrm{pD}_{2}$ and $\mathrm{E}_{\max }$ of 2.46 \pm 0.12 and $2.14 \pm 0.32 \mathrm{~g}(\mathrm{~N}=9)$, respectively (Figure 2). The curve for trimethylsulfonium was concentration-dependently reduced by atropine (1, 10 and $100 \mathrm{nM})$ without changes in $\mathrm{pD}_{2}$ values. In contrast, atropine antagonized methacholine-induced contractions in a purely competitive manner, yielding a Schild plot regression line with a $\mathrm{pA}_{2}$ value of 9.58 and a slope of $0.88 \pm 0.09$ (correlation coefficient $0.95, \mathrm{~N}=12$ ). Furthermore, 
at 1,3 or $10 \mathrm{mM}$, trimethylsulfonium failed to affect rat jejunum responsiveness to the selective muscarinic receptor agonist methacholine. The $\mathrm{pD}_{2}$ and $\mathrm{E}_{\max }$ values obtained for methacholine in the absence or presence of $10 \mathrm{mM}$ trimethylsulfonium were $6.06 \pm$ 0.11 and $3.12 \pm 0.18 \mathrm{~g}(\mathrm{~N}=12)$ and $5.93 \pm$ 0.31 and $2.43 \pm 0.25 \mathrm{~g}(\mathrm{~N}=4)$, respectively.

\section{Effect of trimethylsulfonium on nicotinic receptors}

Trimethylsulfonium and nicotine displaced $\left[{ }^{3} \mathrm{H}\right]$-nicotine binding from rat diaphragm muscle membranes and the $K_{\mathrm{i}}$ values for both ligands were of the same order of magnitude, i.e., 27.1 and $6.6 \mu \mathrm{M}$, respectively (Figure 3 ), suggesting that trimethylsulfonium has a direct effect on nicotinic receptors.

In fact, trimethylsulfonium contracted frog skeletal muscle in a concentration-dependent manner, with a $\mathrm{pD}_{2}$ value of $2.70 \pm$ 0.06 and an $\mathrm{E}_{\max }$ similar to carbachol (4.16 \pm $0.90, \mathrm{~N}=12$, and $3.32 \pm 0.73 \mathrm{~g}, \mathrm{~N}=12$, respectively) (Figure 4A). The nicotinic blocker d-tubocurarine antagonized trimethylsulfonium and carbachol concentrationresponse curves in a competitive fashion, yielding a Schild plot regression line with $\mathrm{pA}_{2}$ values of 5.79 and 5.81 , respectively, and a slope of $1.12 \pm 0.17$ (correlation coefficient $0.81, \mathrm{~N}=23$ ) and $0.98 \pm 0.15$ (correlation coefficient $0.81, \mathrm{~N}=20$ ), respectively (Figure 4B).

\section{Discussion}

In the present study we examined the action of trimethylsulfonium on cholinergic systems in order to assess its functional and binding properties in terms of muscarinic and nicotinic receptors.

Since trimethylsulfonium antagonizes heart vagus nerve effect $(6,7)$, the first hypothesis was that trimethylsulfonium blocks muscarinic receptors. However, since tri- methylsulfonium displaced $\left[{ }^{3} \mathrm{H}\right]-\mathrm{QNB}$ binding with a very low affinity and it did not block the effect of methacholine on rat jejunum, this initial hypothesis was not confirmed. On the other hand, trimethylsulfonium itself promoted a concentration-dependent contraction of the rat jejunum, which was not competitively inhibited by atropine, indicating that trimethylsulfonium acts by a mechanism independent of muscarinic receptors.

It is well known that contraction of intestinal smooth muscle can be elicited by sev-
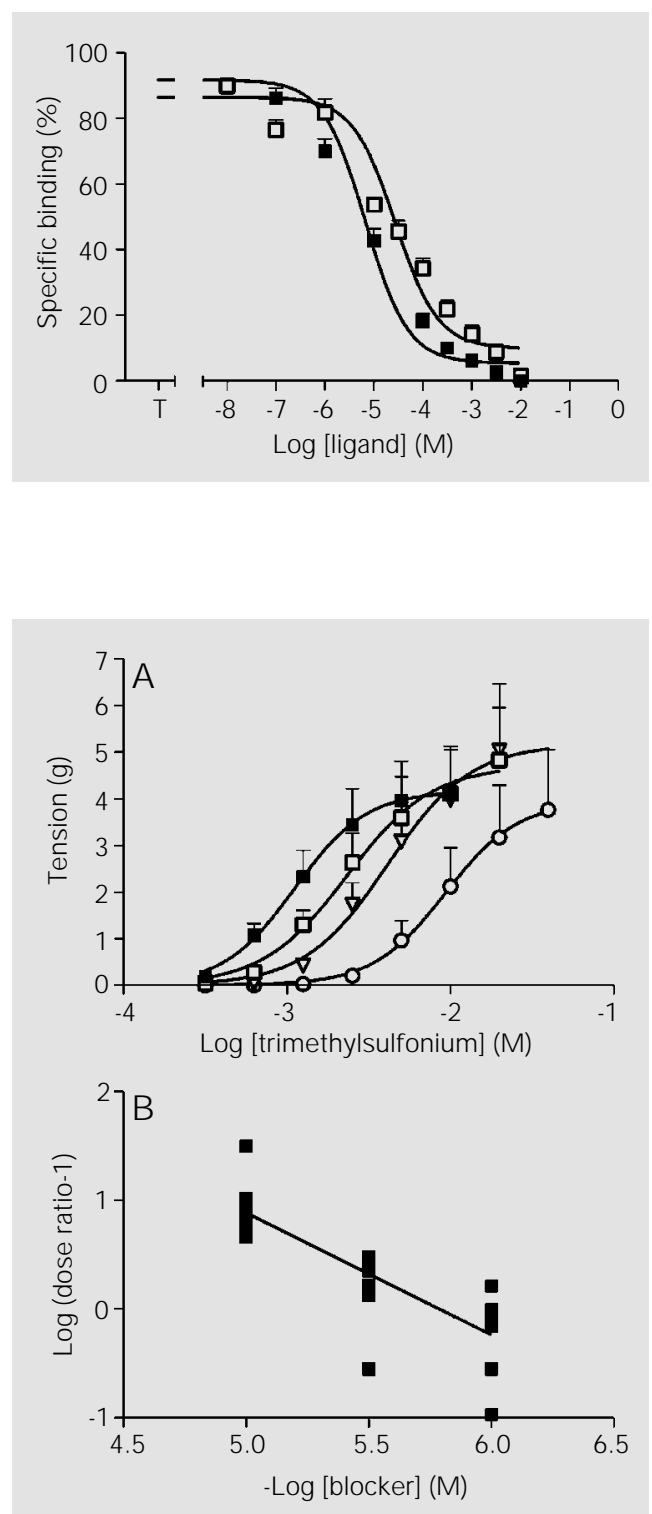

Figure 3. Inhibition of specific [ $\left.{ }^{3} \mathrm{H}\right]-$ nicotine binding to membranes isolated from rat diaphragm by unlabeled nicotine (filled squares, $\mathrm{N}=8$ ) or trimethylsulfonium (open squares, $\mathrm{N}=$ 8). Membranes were incubated with $\left[{ }^{3} \mathrm{H}\right]$-nicotine and unlabeled compounds for $1 \mathrm{~h}$ at room temperature in Tris- $\mathrm{HCl}$ buffer. Specific binding was calculated by subtracting the nonspecific binding measured in the presence of unlabeled $10 \mathrm{mM}$ nicotine from total binding $(\mathrm{T})$. Data are reported as means $\pm \mathrm{SEM}$.

Figure 4. A, Cumulative concentration-response curves (1-h interval) for trimethylsulfonium in frog rectus abdominis muscle, in the absence (filled squares, $\mathrm{N}$ $=12$ ) and in the presence of 1 $\mu \mathrm{M}$ d-tubocurarine (open squares, $\mathrm{N}=9$ ), $3 \mu \mathrm{M}$ d-tubocurarine (inverted triangles, $\mathrm{N}=8$ ) and $10 \mu \mathrm{M}$ d-tubocurarine (circles, $\mathrm{N}=7$ ). The antagonist was applied $1 \mathrm{~h}$ before the agonist. Data are reported as means \pm SEM. B, Schild plot of the antagonism of the response of trimethylsulfonium by d-tubocurarine. The line was calculated by linear regression analysis. 
eral neurotransmitters acting directly on the muscle or through the enteric nervous system. Acetylcholine, acting on nicotinic acetylcholine receptors, is the main excitatory neurotransmitter in the myenteric plexus (13). Therefore, trimethylsulfonium could act presynaptically by releasing acetylcholine, which will act on muscarinic receptors of the muscle. In this case, atropine would not be able to displace trimethylsulfonium from its receptor, but would block the effect of endogenous acetylcholine acting on muscarinic receptors. A similar effect has been observed in the prostatic portion of the rat vas deferens where stimulation of nicotinic presynaptic cholinoreceptors induced the release of neurotransmitters, and the blockade of postsynaptic receptors only reduced the maximal response to nicotinic agonists (14). However, since the release of acetylcholine was not directly measured it is not possible to rule out that trimethylsulfonium simultaneously releases other neurotransmitters which contract the rat jejunum preparation, or even acts on smooth muscle cells through a mechanism independent of muscarinic stimulation. Since atropine only reduced the maximal response to trimethylsulfonium in rat jejunum, we decided to test if this drug was able to bind to and stimulate nicotinic receptors.

In fact, trimethylsulfonium displaced $\left[{ }^{3} \mathrm{H}\right]$-nicotine binding in a manner similar to nicotine. In addition, the trimethylsulfoniuminduced concentration-response curve for rectus abdominis muscle was antagonized by d-tubocurarine in a competitive manner. The $\mathrm{pA}_{2}$ value for d-tubocurarine determined using trimethylsulfonium as agonist did not differ from that obtained with carbachol (present study), and was only slightly lower than the values estimated by other authors using frog cutaneous pectoris muscle $\left(\mathrm{pA}_{2}=\right.$ $6.4)(15,16)$. It is interesting to note that the presence of the three methyl radicals in the trimethylsulfonium molecule favors nicotinic over muscarinic action. N-methyl-carbamylcholine, a carbachol analogue, is selective for nicotinic receptors, while carbachol binds to both nicotinic and muscarinic receptors (17).

\section{Acknowledgments}

The technical assistance of Débora Aparecida de Moura is gratefully acknowledged. We are indebted to Wagner Marcelo Zago for valuable discussions.

\section{References}

1. Winkler LR (1961). Preliminary tests of the toxin extracted from Californian sea hares of the genus Aplysia. Pacific Science, 15: 211-214.

2. Winkler LR, Tilton BE \& Hardinge MG (1962). Predation on the Californian sea hares, Aplysia californica, Cooper, by the solitary grate anemone, Anthopleura xanthogrammica, Brandt, and the effect of the sea hare toxins and acetylcholine on anemone muscles. Pacific Science, 16: 286-290.

3. Blankenship J E, Lanclais PJ \& Kittredge JS (1975). Identification of a cholinomimetic compound in the digestive gland of Aplysia californica. Comparative Biochemistry and Physiology, 51C: 129-137.

4. Shiomi K, Ishii M, Shimakura K, Naga- shima Y \& Chino M (1998). Tigloylcholine: a new choline ester toxin from the hypobranchial gland of two species of muricid gastropods (Thais clavigera and Thais bronni ). Toxicon, 36: 795-798.

5. Freitas A, Freitas J C \& Roque NF (1994). Quatemary ammonium compounds from Aplysia brasiliana (Mollusca, Opisthobranchia). XI Annual Meeting of the Brazilian Society of Chemistry, May 26-29, 1994, Caxambu, MG, Brazil (Abstract).

6. Freitas JC (1977). Action of crude and fractioned homogenates of the midgut gland of the sea hare Aplysia brasiliana, Rang 1928, on some cholinoceptive structures. Comparative Biochemistry and Physiology, 56C: 57-61.

7. Freitas J C, Freitas A \& Roque NF (1995).
Trimethylsulfonium chloride isolated from the midgut gland of Aplysia brasiliana prevents the vagus nerve effects on the toad's heart. 5th Pan-American Symposium on Animal, Plant and Microbial Toxins, J uly 30 to August 4, 1995, Frederick, MD, USA (Abstract).

8. Kobashi $\mathrm{YL}$, Breuing EP \& Markus RP (1985). Age-related changes in the reactivity of the rat jejunum to cholinoceptor agonists. European J ournal of Pharmacology, 115: 133-138.

9. Bradford MM (1976). A rapid and sensitive method for the quantification of microgram quantities of protein utilizing the principle of protein dye binding. Analytical Biochemistry, 72: 248-254.

10. Yamamura HI \& Snyder SH (1974). Mus- 
carinic cholinergic binding in rat brain. Proceedings of the National Academy of Sciences, USA, 71: 1725-1729.

11. Brioni J D, Decker MW, Sullivan JP \& Arneric SP (1997). The pharmacology of (-)-nicotine and novel cholinergic channel modulators. Advances in Pharmacology, 37: 153-214.

12. Arunlakshana O \& Schild HO (1959). Some quantitative uses of drug antagonists. British J ournal of Pharmacology, 14: 48-58.

13. Schneider DA, Perrone $M \&$ \& Galligan JJ (2000). Nicotinic acetylcholine receptors at sites of neurotransmitter release to the guinea pig intestinal circular muscle. J ournal of Pharmacology and Experimental Therapeutics, 294: 363-369.

14. Carneiro RCG \& Markus RP (1990). Presynaptic nicotinic receptors involved in release of noradrenaline and ATP from the prostatic portion of the rat vas deferens. $J$ ournal of Pharmacology and Experimental Therapeutics, 255: 95-100.

15. Colquhoun D, Dreyer F \& Sheridan RE (1979). The actions of tubocurarine at the frog neuromuscular junction. J ournal of Physiology, 293: 247-284.
16. Colquhoun D \& Sheridan RE (1982). The effect of tubocurarine competition on the kinetics of agonist action on the nicotinic receptor. British J ournal of Pharmacology, 75: 77-86.

17. Boksa P, Quik M, Mitchell J B, Collier B, O'Neil W \& Quirion R (1989). Pharmacological activity of $\mathrm{N}$-methyl-carbamylcholine, a novel acetylcholine receptor agonist with selectivity for nicotinic receptors. European J ournal of Pharmacology, 173: 93108. 